\title{
Wpływ wysiłkowego nietrzymania moczu stopnia I na aktywność ruchową kobiet w zależności od stanu odżywienia określonego za pomocą wskaźnika masy ciała
}

\section{The influence of grade 1 stress urinary incontinence on the physical activity of women depending on nutritional status as defined by the Body Mass Index}

\author{
Magdalena Ptak, Hanna Mosiejczuk, Aleksandra Szylińska, Iwona Rotter \\ Samodzielna Pracownia Rehabilitacji Medycznej Pomorskiego Uniwersytetu Medycznego w Szczecinie \\ ul. Żołnierska 54, 71-210 Szczecin \\ Kierownik: dr n. med. Iwona Rotter
}

\begin{abstract}
Introduction: Stress urinary incontinence (SUI) and obesity are problems recognized by the World Health Organization as social diseases. The International Continence Society has estimated that about $10-40 \%$ of women have problems with urinary incontinence. Overweight states and obesity are among the biggest health problems in perimenopausal women.

The aim of the study was to analyze the impact of SUI on the physical activity (PA) of women in relation to their body weight. Material and methods: The study comprised 54 women aged 41-67 years with SUI. Anthropometric measurements were taken. Physical activity was examined by specially designed questionnaires. The statistical significance was calculated in the Statistica 12 software using normality tests, correlation coefficient, nonparametric tests, and a post-hoc test.

Results: The mean age of subjects was $55 \pm 7$ years. Body Mass Index (BMI) in subjects was normal (N1) - 11 (20.4\%),
\end{abstract}

\section{STRESZCZENIE}

Wstęp: Wysiłkowe nietrzymanie moczu (WNM) i otyłość są problemami uznanymi przez Światową Organizację Zdrowia (World Health Organization - WHO) za choroby społeczne. Według International Continence Society 10-40\% kobiet ma kłopoty z nietrzymaniem moczu (NM). Nadwaga i otyłość stanowią jeden z największych problemów zdrowotnych kobiet w okresie okołomenopauzalnym.

Celem przeprowadzonych badań była analiza wpływu WNM na aktywność ruchową (AR) kobiet w zależności od masy ciała. Materiał i metody: W badaniu wzięły udział 54 kobiety w wieku 41-67 lat z WNM. Wykonano pomiary antropometryczne. Aktywność ruchowa została zbadana za pomocą kwestionariuszy autorskich. Istotność statystyczną obliczono w programie Statistica 12 testami normalności rozkładu, współczynnika korelacji oraz testami nieparametrycznymi i post-hoc.

Wyniki: Średnia wieku badanych wynosiła $55 \pm 7$ lat. Wskaźnik masy ciała (Body Mass Index - BMI) u badanych kształtował się or indicated the state of being overweight (N2) - $33(59.2 \%)$ or obese (N3) - 11 (20.4\%); 94\% (51) patients had the android body type and $6 \%$ (3) had the gynoidal body type. PA before the onset of problems with SUI was assessed by patients as a sedentary lifestyle $-12(22.2 \%)$, active $-23(42.6 \%)$ or mixed - 19 (35.2\%). Subjects, when asked how strong the impact of SUI on their PA was, answered: minor 13 (24.1\%), moderate - 14 (25.9\%), very strong - 27 (50\%). No statistically significant differences between PA and SUI were found in N1, N2 and N3 groups.

Conclusions: Overweight patients reported the strongest impact of SUI on their PA, but the differences between the analysed groups were not significant. Most subjects had the android body type, which was assessed by means of WHR.

Keywords: stress urinary incontinence, physical activity, menopause, overweight, obesity.

\section{WSTĘP}

Wysiłkowe nietrzymanie moczu (WNM) jest problemem uznawanym przez Światową Organizację Zdrowia (World Health

następująco: w normie (N1) - 11 (20,4\%), z nadwagą (N2) - 33 (59,2\%), otyłość (N3) - 11 (20,4\%); 94\% (51 osób) stanowiły pacjentki o budowie ciała androidalnej, 6\% (3 osoby) o gynoidalnej. Aktywność ruchową przed pojawieniem się problemów z WNM pacjentki oceniały jako tryb życia: siedzący - 12 (22,2\%), aktywny - 23 (42,6\%), mieszany - 19 (35,2\%). Na pytanie dotyczące wpływu pojawienia się problemów z WNM na AR pacjentki odpowiadały: trochę - 13 (24,1\%), umiarkowanie - 14 (25,9\%), bardzo - 27 (50\%). Nie wykazano różnic istotnych statystycznie w grupach N1, N2, N3 pod względem wpływu WNM na AR. Wnioski: Największą uciążliwość WNM wpływającą na AR odczuwały pacjentki z nadwagą. Nie została jednak wykazana istotna zależność $\mathrm{w}$ tym zakresie. $\mathrm{W}$ badanej grupie chorych przeważający był androidalny typ budowy ciała oceniany za pomocą wskaźnika WHR.

Słowa kluczowe: nietrzymanie moczu, aktywność ruchowa, menopauza, nadwaga, otyłość. 
sygnalizuje problemy z utrzymaniem moczu [1]. Szacuje się, iż procent może być wyższy, ponieważ dolegliwość ta jest uznawana za wstydliwą [2].

W swojej pracy Bump [3] podaje czynniki ryzyka NM wywołujące, predysponujące, dekompensacyjne oraz promujące. Pośród nich można wyróżnić takie, które przyczyniać się będą zarówno do wystąpienia NM, jak i do powstawania otyłości (wiek kobiety, choroby środowiskowe, poziom aktywności fizycznej, dieta, dysfunkcje jelit, menopauza). Otyłość jest jednocześnie czynnikiem, który sprzyja pojawieniu się problemów inkontynencji i wpływa na nasilenie tej dolegliwości.

Nadwaga i otyłość są jednym z największych problemów zdrowotnych kobiet w okresie okołomenopauzalnym. Wpływają zarówno na zmniejszenie aktywności ruchowej, jak i są czynnikiem etiologicznym powstawania WNM. Zmniejszenie aktywności ruchowej w tym czasie związane jest zarówno ze zwiększeniem masy ciała, jak i NM [4]. Według wyników badań aktywność fizyczna wpływa na poprawę zdrowia i jakości życia. W pracy Skrzypulec i wsp. [5] zauważono, że umiarkowany poziom aktywności fizycznej w okresie okołomenopauzalnym ma wpływ na zmniejszenie objawów klimakterycznych i poprawę jakości życia seksualnego, a redukcja masy ciała o 5-10\% powoduje zmniejszenie epizodów utraty moczu o 50\% [6]. Wśród starszych osób zalecana jest aktywność o małym nasileniu (np. tylko spacery), jako sposób będący najbardziej optymalnym wyjściem, biorąc pod uwagę wiek oraz epizody utraty moczu [7]. Podobne wnioski nasuwają się po analizie wyników badań Virtuoso i wsp. [8]. Regularna umiarkowana aktywność fizyczna uprawiana w grupie starszych kobiet wpływała na poprawę funkcji dna miednicy (wzrost aktywności włókien wolnokurczliwych), ocenianą perineometrem.

Celem przeprowadzonych badań była analiza wpływu WNM stopnia I na aktywność ruchową (AR) kobiet w zależności od wartości wskaźnika masy ciała (Body Mass Index - BMI). W hipotezie badawczej założono, iż wpływ WNM na AR różni się w zależności od masy ciała. Drugoplanowym celem była ocena typu otyłości za pomocą współczynnika talia-biodra (waist-hip ratio - WHR).

\section{MATERIA I I METODY}

W badaniu wzięły udział 54 kobiety w przedziale wiekowym 41-67 lat z województwa zachodniopomorskiego. Kobiety z WNM stopnia I zostały zakwalifikowane na podstawie badania urodynamicznego przeprowadzonego w klinice uroginekologicznej. W badanej grupie czas wystąpienia WNM nie był dłuższy niż rok (wg subiektywnej oceny pacjentki).

Pomiaru masy ciała i wzrostu dokonano z użyciem standardowej wagi lekarskiej, a obwodu na wysokości talii oraz bioder - z użyciem miary antropometrycznej.

Wskaźnik masy ciała obliczany jest u pacjentek wg wzoru masy ciała podanej w kilogramach podzielonej przez kwadrat wysokości podanej w metrach. Pacjentki zostały za pomocą tego wskaźnika podzielone na 3 grupy badane: N1 - grupa o budowie ciała prawidłowej $\left(<24,99 \mathrm{~kg} / \mathrm{m}^{2}\right), \mathrm{N} 2$ - z nadwagą $\left(25,0-29,99 \mathrm{~kg} / \mathrm{m}^{2}\right)$ i N3 - z otyłością $\left(>30,0 \mathrm{~kg} / \mathrm{m}^{2}\right)$.

Średnia wieku badanych pacjentek wynosiła $55 \pm 7$ lat. Wskaźnik masy ciała u badanych kobiet kształtował się następująco: w normie, grupa $\mathrm{N} 1-12$ pacjentek $(22,2 \%)$, z nadwagą, grupa N2 - 31 pacjentek $(57,4 \%)$ oraz otyłość, grupa N3 - 11 pacjentek (20,4\%). Średni wiek pacjentek z normalną masą ciała wynosił $55 \pm 8$ lat, z nadwagą $57 \pm 7$ lat, a z otyłością $52 \pm 6$ lat; $65 \%$ (35 osób) to kobiety miesiączkujące, a 35\% - niemiesiączkujące (tab. 1).

Gromadzenie się tkanki tłuszczowej (typ budowy ciała) zostało opisane z wykorzystaniem wskaźnika WHR, gdzie u kobiet proporcje obwodu tali do obwodu bioder są oceniane wg podanej zasady: $\geq 0,8$ to budowa typu androidalnego (typ otyłości brzusznej, ,jabłka”) oraz <0,8 - typu gynoidalnego (typ otyłości pośladkowo-udowej, „gruszki”). Do pomiaru obwodów wykorzystano miarę antropometryczną, wykonując je na dwóch ustalonych wysokościach: w talii - w najwęższym miejscu położonym pomiędzy talerzami biodrowymi, a także żebrami, oraz w biodrach - w najszerszym ich miejscu. Zdecydowaną większość - 94\% (51 osób) stanowiły kobiety o budowie ciała androidalnej, a tylko 6\% (3 osoby) - gynoidalnej.

Do badania poziomu trybu życia pacjentek przed wystąpieniem WNM użyto autorskiego kwestionariusza, w którym oceniały one subiektywnie swoją aktywność, zaznaczając odpowiednio: tryb życia mieszany, tryb życia aktywny, tryb życia siedzący. Codzienna AR przed pojawieniem się problemów z WNM, jaką pacjentki zgłaszały w ankiecie, kształtowała się następująco: siedzący tryb życia - 12 pacjentek $(22,2 \%)$, aktywny tryb życia - 23 (42,6\%) oraz mieszany tryb życia - 19 $(35,2 \%)$ - tabela $2 . \mathrm{Z} 11$ badanych otyłych pacjentek z grupy N3, $8(72 \%)$ zgłaszało siedzący tryb życia, a żadna z tej grupy nie podała trybu aktywnego; 3 osoby deklarowały tryb życia mieszany. Z najliczniejszej grupy N2 (nadwaga), 13 (42\%) pacjentek zgłaszało mieszany tryb życia. Siedem pacjentek z masą ciała w normie oceniło swój tryb życia jako mieszany, 3 - aktywny,

TABELA 1. Charakterystyka badanych grup N1, N2, N3

\begin{tabular}{|c|c|c|c|c|}
\hline & \multirow{2}{*}{$\begin{array}{c}\text { Wartość BMI } \\
\left(\mathrm{kg} / \mathrm{m}^{2}\right)\end{array}$} & \multirow{2}{*}{$\begin{array}{l}\text { Średni wiek } \\
\text { (w latach) }\end{array}$} & \multicolumn{2}{|c|}{ Status menopauzalny } \\
\hline & & & przedmenopauzalny & pomenopauzalny \\
\hline Prawidłowa masa ciała (N1) & $12(22,2 \%)$ & $55 \pm 8$ & $5(41,7 \%)$ & $7(58,3 \%)$ \\
\hline Otyłość (N3) & $11(20,4 \%)$ & $52 \pm 6$ & $5(45,5 \%)$ & $6(54,5 \%)$ \\
\hline Ogółem & 54 & $55 \pm 7$ & $19(35,2 \%)$ & $35(64,8 \%)$ \\
\hline
\end{tabular}

BMI - wskaźnik masy ciała 
TABELA 2. Tryb życia pacjentek w zależność od wskaźnika masy ciała

\begin{tabular}{lcccc}
\hline & $\begin{array}{c}\text { Tryb życia } \\
\text { siedzący }\end{array}$ & $\begin{array}{c}\text { Tryb życia } \\
\text { aktywny }\end{array}$ & $\begin{array}{c}\text { Tryb życia } \\
\text { mieszany }\end{array}$ & $\begin{array}{c}\text { Test } \\
\text { post-hoc } \\
\text { Tukeya }\end{array}$ \\
\hline $\begin{array}{l}\text { Prawidłowa } \\
\text { masa ciała (N1) }\end{array}$ & $2(16,7 \%)$ & $3(25 \%)$ & $7(58,3 \%)$ & $\mathrm{p}<0,048$ \\
\hline Nadwaga (N2) & $9(29 \%)$ & $9(29 \%)$ & $13(42 \%)$ & $\mathrm{BI}$ \\
\hline Otyłość (N3) & $8(72,7 \%)$ & $0(0 \%)$ & $3(27,3 \%)$ & $\mathrm{p}<0,036$ \\
\hline Ogółem & 19 & 12 & 23 & $\mathrm{p}<0,023$ \\
\hline
\end{tabular}

Bl - brak istotności

2 - siedzący. Wykazano istotnie statystycznie różnice pomiędzy BMI a trybem życia pacjentek przed wystąpieniem WNM, $p=0,023, r=-0,31$ (tab. 2).

Do oceny wpływu WNM na AR wykorzystano pytanie: „Czy Pani problemy z pęcherzem wpływają na aktywność fizyczną wyrażoną w postaci spacerów, rekreacyjnego uprawiania sportu, biegania?". Pacjentki zakreślały odpowiedź spośród 4 możliwości: wcale, trochę, umiarkowanie oraz bardzo.

Do oceny wpływu WNM na zmianę aktywności fizycznej wykorzystano takie samo pytanie: „Czy Pani problemy z pęcherzem wpływają na aktywność fizyczną wyrażoną w postaci spacerów, rekreacyjnego uprawiania sportu, biegania?". Pacjentki zakreślały odpowiedź spośród 4 możliwości: wcale, trochę, umiarkowanie oraz bardzo. Z użyciem analogowej skali wizualnej (visual analog scale - VAS) badane kobiety określały również uciążliwość, jakiej doświadczają z powodu problemów z nietrzymaniem moczu. Na 10-stopniowej skali zaznaczano od o (wcale nie zakłóca) do 10 (w dużym stopniu).

W analizie statystycznej wykonano statystyki opisowe, podając średnią i odchylenie standardowe, medianę, minimalne oraz maksymalne wartości. Podział na grupy wg wskaźnika BMI sprawił, że grupy N1, N2 i N3 były niejednorodne pod względem takich cech, jak: wiek, miesiączkowanie lub menopauza oraz tryb życia, jaki wiodły przed wystąpieniem objawów. Do zbadania zależności użyto współczynnika korelacji R Spearmana. W analizie nie uzyskano krzywej Gaussa. Do testowania normalności rozkładu badanej zmiennej BMI użyto testu Shapiro-Wilka. Hipotezę zerową, zakładającą normalność rozkładu, należało odrzucić. W związku z tym do dalszej analizy porównań międzygrupowych został użyty nieparametryczny test Kruskala-Wallisa. Po wystąpieniu w teście Kruskala-Wallisa istotności statystycznej wykonano analizę post-hoc przy pomocy testu Tukeya dla nierównych liczności.
Jako istotny statystycznie przyjęto poziom $\mathrm{p}<0,05$. Analizę statystyczną wykonano przy użyciu pakietu Statistica 12.

Badania pacjentek zostały przeprowadzone po zaakceptowaniu przez Komisję Bioetyczną z dnia 30.09.2013 r.

\section{WYNIKI}

W autorskim kwestionariuszu na pytanie dotyczące wpływu pojawienia się problemów z NM na aktywność fizyczną pacjentki odpowiadały kolejno: trochę - 13 (24,1\%), umiarkowanie -14 (25,9\%), bardzo - 27 (50\%). Żadna z pacjentek nie oceniła wpływu wystąpienia WNM na AR jako „wcale” (bez zmiany); 15 osób z WNM w grupie N2 (nadwaga) oceniło, że problem ten bardzo wpłynął na ich AR. Tylko 1 osoba z grupy N3 (otyłość) podała, że WNM „trochę" wpłynęło na jej AR. Nie wykazano istotnych statystycznie różnic w AR po wystąpieniu WNM w badanych grupach (N1, N2, N3) (p = 0,74; r = 0,094; test statystyczny Kruskala-Wallisa) - tabela 3.

TABELA 3. Subiektywna ocena wpływu problemów z nietrzymaniem moczu na codzienną aktywność ruchową w grupach N1, N2, N3

\begin{tabular}{lcccc}
\hline & \multicolumn{4}{c}{ Czy Pani problemy z pécherzem wpływają } \\
& wa aktywność fizyczną? & \\
\cline { 2 - 5 } & wcale & trochę & $\begin{array}{c}\text { umiarko- } \\
\text { wanie }\end{array}$ & bardzo \\
\hline $\begin{array}{l}\text { Prawidłowa } \\
\text { masa ciała (N1) }\end{array}$ & $0(0 \%)$ & $4(33,3 \%)$ & $2(16,7 \%)$ & $6(50 \%)$ \\
\hline Nadwaga (N2) & $0(0 \%)$ & $8(25,8 \%)$ & $8(25,8 \%)$ & $15(48,4 \%)$ \\
\hline Otyłość (N3) & $0(0 \%)$ & $1(9,1 \%)$ & $4(36,4 \%)$ & $6(54,6 \%)$ \\
\hline Ogółem & 0 & 13 & 14 & 27 \\
\hline Test Kruskala-Wallisa: $\mathrm{H}(2, \mathrm{n}=54)=0,597 ; \mathrm{p}=0,742 ; \mathrm{r}=0,094$
\end{tabular}

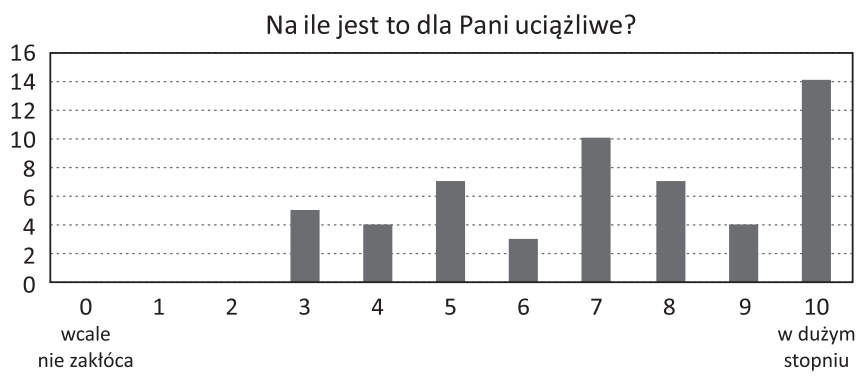

RYCINA 1. Odpowiedzi wszystkich badanych pacjentek (54 osoby) na pytanie „Na ile problemy z NM są uciążliwe?" (w skali VAS)

TABELA 4. Deklarowana uciążliwość spowodowana wysiłkowym nietrzymaniem moczu w zależności od stanu odżywienia

\begin{tabular}{|c|c|c|c|c|c|c|c|c|c|}
\hline \multirow{2}{*}{$\begin{array}{c}\text { Zakres wartości } \\
\text { BMI }\end{array}$} & \multicolumn{9}{|c|}{ Uciążliwość } \\
\hline & 3 & 4 & 5 & 6 & 7 & 8 & 9 & 10 & ogółem \\
\hline $\begin{array}{l}\text { Prawidłowa } \\
\text { masa ciała (N1) }\end{array}$ & $\begin{array}{c}3 \\
(5,56 \%)\end{array}$ & $\begin{array}{c}0 \\
(0 \%)\end{array}$ & $\begin{array}{c}1 \\
(1,85 \%)\end{array}$ & $\begin{array}{c}2 \\
(3,7 \%)\end{array}$ & $\begin{array}{c}1 \\
(1,85 \%)\end{array}$ & $\begin{array}{c}2 \\
(3,7 \%)\end{array}$ & $\begin{array}{c}0 \\
(0 \%)\end{array}$ & $\begin{array}{c}3 \\
(5,56 \%)\end{array}$ & $\begin{array}{c}12 \\
(22,22 \%)\end{array}$ \\
\hline Nadwaga (N2) & $\begin{array}{c}2 \\
(3,7 \%)\end{array}$ & $\begin{array}{c}3 \\
(5,56 \%)\end{array}$ & $\begin{array}{c}6 \\
(11,11 \%)\end{array}$ & $\begin{array}{c}1 \\
(1,85 \%)\end{array}$ & $\begin{array}{c}8 \\
(14,81 \%)\end{array}$ & $\begin{array}{c}3 \\
(5,56 \%)\end{array}$ & $\begin{array}{c}2 \\
(3,7 \%)\end{array}$ & $\begin{array}{c}6 \\
(11,11 \%)\end{array}$ & $\begin{array}{c}31 \\
(57,41 \%)\end{array}$ \\
\hline Otyłość (N3) & $\begin{array}{c}0 \\
(0 \%)\end{array}$ & $\begin{array}{c}1 \\
(1,85 \%)\end{array}$ & $\begin{array}{c}0 \\
(0 \%)\end{array}$ & $\begin{array}{c}0 \\
(0 \%)\end{array}$ & $\begin{array}{c}1 \\
(1,85 \%)\end{array}$ & $\begin{array}{c}2 \\
(3,7 \%)\end{array}$ & $\begin{array}{c}2 \\
(3,7 \%)\end{array}$ & $\begin{array}{c}5 \\
(9,26 \%)\end{array}$ & $\begin{array}{c}11 \\
(20,37 \%)\end{array}$ \\
\hline Ogółem & $\begin{array}{c}5 \\
(9,26 \%)\end{array}$ & $\begin{array}{c}4 \\
(7,41 \%)\end{array}$ & $\begin{array}{c}7 \\
(12,96 \%)\end{array}$ & $\begin{array}{c}3 \\
(5,56 \%)\end{array}$ & $\begin{array}{c}10 \\
(18,52 \%)\end{array}$ & $\begin{array}{c}7 \\
(12,96 \%)\end{array}$ & $\begin{array}{c}4 \\
(7,41 \%)\end{array}$ & $\begin{array}{c}14 \\
(25,93 \%)\end{array}$ & $\begin{array}{c}54 \\
(100 \%)\end{array}$ \\
\hline
\end{tabular}


Z użyciem VAS badane kobiety określały również uciążliwość, jakiej doświadczają z powodu problemów z nietrzymaniem moczu. Na 10-stopniowej skali zaznaczano od o (wcale nie zakłóca) do 10 (w dużym stopniu). W całej badanej grupie pacjentek wyniki kształtowały się następująco: w skali 0-2 o pacjentek, 3- 5 pacjentek, 4 - 4 pacjentki, 5- 7 pacjentek, 6 3 pacjentki, 7 - 10 pacjentek, 8 - 7 pacjentek, $9-4$ pacjentki, 10 („w dużym stopniu”) - 14 pacjentek.

\section{DYSKUSJA}

Nietrzymanie moczu to problem uznawany przez WHO za chorobę społeczną. Według ICS dotyczy prawie 40\% pacjentek. Około 33\% kobiet będących w okresie okołomenopauzalnym sygnalizuje problemy z utrzymaniem moczu [1].

Głównym celem badania była ocena wpływu WNM na AR pacjentek w zależności od stanu odżywiania określonego za pomocą BMI. Pacjentki przed pojawieniem się WNM zgłaszały aktywny (12), mieszany (23) lub siedzący (19) tryb życia, a po pojawieniu się WNM ich aktywność malała. Oceniły, że to właśnie WNM wpłynęło trochę, umiarkowanie lub bardzo na ich funkcjonowanie w tej sferze. Żadna z nich nie uznała, że ta dolegliwość w ogóle („wcale”) nie wpłynęła na AR.

Pojawieniu się WNM sprzyja wiele czynników. Do często spotykanych zalicza się nadwagę i otyłość. W badaniach Dąbrowskiej i wsp. [4] wykazano, że poziom aktywności maleje wraz ze wzrostem BMI. W badaniu Wilamowskiej i Sobczuk [6] kobiety zakwalifikowane do diagnostyki urodynamicznej (BMI $>25 \mathrm{~kg} / \mathrm{m}^{2}$ ) stanowiły $86,6 \%$. Według danych z piśmiennictwa podwyższenie wartości BMI wpływa na nasilenie objawów NM $[6,9,10]$. Warto zwrócić szczególną uwagę na pracę Nygaard i wsp. [11], w której podkreślono, że na występowanie problemów z dnem miednicy, takich jak NM czy zaburzenia statyki narządu rodnego (pelvic organ prolapse - POP), może wpływać wiele czynników. Do słabo poznanych należy wpływ poziomu aktywności fizycznej. Nygaard i wsp. proponują utworzenie/ budowanie schematu postępowania z pacjentkami z niewydolnością przepony moczowo-płciowej tak, aby ocena wszystkich czynników ryzyka była wnikliwa i pozwoliła na wprowadzenie spójnego podejścia [11].

Subak i wsp. [10] wykazali wzrost objawów NM wraz ze wzrostem BMI, gdzie w przedziale BMI 25-29,9 kg/m² określającym nadwagę NM sygnalizowało 21,7\% pacjentek, a w przedziale $30-39,9 \mathrm{~kg} / \mathrm{m}^{2}$ określającym otyłość problemy miało 30,1\%. Zostało również zaobserwowane, że wskaźnik BMI $>30 \mathrm{~kg} / \mathrm{m}^{2}$ dwukrotnie częściej koreluje z NM u kobiet o prawidłowej masie ciała. Jednocześnie stwierdzono, że zwiększenie wartości BMI o 1-2 jednostki powoduje zwiększenie częstości występowania NM o 19\% [12]. Według wyników badań Pinto i wsp. [13] utrata wagi oraz wzrost aktywności fizycznej są silnie związane z oceną jakości życia mierzoną za pomocą kwestionariusza jakości życia warunkowanej stanem zdrowia (health-related quality of life - HRQL). Ciekawym jest, że zmniejszenie częstotliwości występowania epizodów NM (spowodowanej zmniejszeniem masy ciała) nie wpłynęło na polepszenie jakości życia. W obserwacjach Davisa i wsp. spadek hormonów w okresie okołomenopauzalnym sprzyja otyłości pojawiającej się w okolicy brzucha [14]. W badaniach Lamberta i wsp. [15] wykazano, że otyłość brzuszna koreluje z występowaniem wzrostu ciśnienia śródbrzusznego, które wraz ze wzrostem wartości obciąża dno miednicy i predysponuje do powstawanie WNM.

Objawy NM narastają wraz z wiekiem [16] i stanowią ogromne wyzwanie współczesnej geriatrii [17]. Znajomość czynników sprzyjających występowaniu NM, do których zaliczamy nadwagę i otyłość, może wpłynąć na uruchomienie wczesnego postepowania eliminującego je w okresie okołomenopauzalnym i stać się świadomym przeciwdziałaniem nasilenia objawów w późniejszym czasie.

\section{WNIOSKI}

1. Największy wpływ WNM na AR odczuwały pacjentki z nadwagą (N2). Nie została jednak wykazana istotna zależność w tym zakresie.

2. Najmniejszy wpływ WNM na AR wskazała pacjentka z grupy otyłych (N3). W badanej grupie chorych przeważający był androidalny typ budowy ciała, oceniany za pomocą wskaźnika WHR.

\section{PIŚMIENNICTWO}

1. Płachta Z, Mazur P, Walaszek P, Skorupski P, Adamiak A, Tomaszewski J, et al. Nietrzymanie moczu u kobiet - epidemiologia i czynniki ryzyka. Prz Menopauzalny 2002;1:28-32.

2. World Federation of Incontinent Patients, UroConti - Stowarzyszenie Osób z NTM, Program Prospołeczny - NTM Normalnie Żyć, Wpływ NTM na koszty społeczno-ekonomiczne w Polsce. http://ntm.pl/upload/file/ Raport_NTM\%20w\%20Polsce.pdf (10.04.2015).

3. Bump RC. Discussion: Epidemiology of urinary incontinence. Urology 1997;50:15-6.

4. Dąbrowska J, Dąbrowska-Galas M, Naworska B, Wodarska M, Plinta R. The role of physical activity in preventing obesity in midlife women. Prz Menopauzalny 2015;14(1):1-7.

5. Skrzypulec V, Dąbrowska J, Drosdzol A. The influence of physical activity level on climacteric symptoms in menopausal women. Climacteric 2010;13(4):355-61.

6. Wilamowska A, Sobczuk A. Otyłość u kobiet zakwalifikowanych do badania urodynamicznego. Prz Menopauzalny 2007;4:204-7.

7. Lee AH, Hirayama F. Physical Activity and urinary incontinence in older adults: A Community - Based Study. Curr Aging Sci 2012;5(1):35-40.

8. Virtuoso JF, Mazo GZ, Menezes EC. Urinary incontinence and perineal muscle function in physically active and sedentary elderly women. Rev Bras Fisioter 2011;15(4):310-7.

9. Kinalski M. Nietrzymanie moczu u otyłych kobiet. Przeg Kardiodiabetol 2009;4(4):181-6.

10. Subak LL, Johnson C, Whitcomb E, Boban D, Saxton J, Brown JS. Does weight loss improve incontinence in moderately obese women? Int Urogynecol J Pelvic Floor Dysfunct 2002;13:40-3.

11. Nygaard I, Shaw J, Egger MJ. Exploring the association between lifetime physical activity and pelvic floor disorders: study and design challenges. Contemp Clin Trials 2012;33(4):819-27. 
12. Goldberg RP, Abramov Y, Botros S, Miller JJ, Gandhi S, Nickolov A, et al. Delivery mode is a major environmental determinant of stress urinary incontinence: results of the Evanston-Northwestern Twin Sisters Study. Am J Obstet Gynecol 2005;193(6):2149-53.

13. Pinto AM, Subak LL, Nakagawa S, Vittinghoff E, Wing RR, Kusek JW, et al. The effect of weight loss on changes in health-related quality of life among overweight and obese women with urinary incontinence. Qual Life Res 2012;21(10):1685-94.
14. Davis SR, Castelo-Branco C, Chedraui P, Lumsden MA, Nappi RE, Shah D, et al. Understanding weight gain at menopause. Climacteric 2012;15(5):419-29.

15. Lambert DM, Marceau S, Forse RA. Intra-abdominal pressure in the morbidly obese. Obes Surg 2005;15(9):1225-32.

16. Jung HB, Kim HJ, Cho ST. A current perspective on geriatric lower urinary tract dysfunction. Korean J Urol 2015;56(4):266-75.

17. Loertzer $H$, Schneider P. Stress incontinence in elderly women. Urologe A 2013, 52(6):813-20 